\title{
The Meaning of Visual Representation Of The COVID-19 Pandemic In The Visual Journals of Children Aged 6-8 Years
}

\author{
Alzena Ardhanareswari Afinidyani ${ }^{1,{ }^{*}}$ Riama Maslan Sihombing ${ }^{2}$ \\ ${ }^{1}$ Institut Teknologi Bandung, Indonesia \\ ${ }^{2}$ Institut Teknologi Bandung, Indonesia \\ *Corresponding author.Email: alzenafinidyani@gmail.com
}

\begin{abstract}
Currently, almost the whole world is affected by the corona virus outbreak or COVID-19. This situation makes children's activities change, they must obey health protocols, stay at home more often, and minimize physical interaction with other people or their closest relatives. The pandemic situation can make children vulnerable to psychological disorders. Parents must know the feelings and experiences of children during the pandemic so that psychological disorders in children can be avoided. To find out the needs of children, it is necessary to build communication between parents and children. One of the communication media that can be used by children as a medium of communication to parents is a visual journal. Like the function used by adults in the process of thinking, visual journals can be useful for children as a medium for thinking and understanding their surroundings. This study was conducted to find out how children's understand and feel about the situation of the COVID-19 pandemic that can be seen from the meaning of children's visual journals. This study uses a descriptive qualitative approach as a way to express meaning in visual journals for children aged 6-8 years about the COVID-19 situation which is analyzed by visual representation theory. Data in the form of drawing and writing of children's visual journals were obtained from observations of three children's visual journal activities at home during the COVID19 pandemic. This study finds that children's visual journals have a meaningful visual representation of their understandings and feelings of the COVID-19 situation.
\end{abstract}

Keywords: Visual Journal, Children, Meaning-making, Visual representation, COVID-19.

\section{INTRODUCTION}

Currently, almost the entire world is affected by the coronavirus or COVID-19 outbreak. This has caused the Indonesian government since April 2020 to implement Pembatasan Sosial Berskala Besar (PSBB) as a step to inhibit the spread of the COVID19. This measure requires the public to limit activities that involve direct physical contact with other people. These restrictions include going to schools and workplaces, being involved in religious activities, conducting activities in public places or facilities, sociocultural activities, transportation, and other activities specifically related to aspects of defense and security [1]. This situation occurs suddenly and requires adjustment from each individual, including children. Their activities now are different compared to before the COVID-19 pandemic. Children are mostly at home and only interact with family members at home. According to a mental health specialist, dr. Predito Prihantoro, SpKJ, said that this pandemic period makes early childhood who is in elementary school or kindergarten vulnerable to psychological disorders [2]. Parents must know the child's feelings and experiences during the pandemic so that children avoid psychological disorders. This can be done by building communication between parents and children.

Visual journal is one of the media that can be used by children as a medium to communicate with parents. Visual journal is a media that combines thinking collaboration of drawing and writing [3]. Like the function used by adults in the thinking process, a visual journal can be useful for children as a medium for thinking and understanding their surroundings. In 
addition, previous research has proven that the use of drawing activities to find out the child's experience in some event, was able to produce more information about the child's feelings and expectations than through oral question and answer activities [4]. Children have a natural ability to express narratives through drawing and writing activities [5]. The activity of making a visual journal allows children to reflect what is on their mind into a new form, which is a symbol or sign. Drawing allows children to reexamine and assess their process of thinking, talk about it with others, and share ideas [6]. So it can be concluded that visual journal activity is a meaningmaking process. Visual journal activities can be carried out by children who are already able to draw and write. According to Lowenfeld and Brittain, children aged 6-8 years are able to produce more details in their marks and can tell stories about the marks they made [7]. Children aged six and over are able to use writing as a mediator, assuming things such as some representational and social works of movement, play and speech [8]. This explained that children aged 6-8 years are in the right age to start visual journaling. The meanings of children signs in visual journal can be understood through the analysis of visual representations. Visual representation explains that visual forms can be equated with semiotic modes that exist in linguistic forms which are characterized by elements called vectors [9].

This study was conducted to find out how children understand and feels about the situation of the COVID-19 pandemic which can be seen from the meaning of visual representations in children's visual journals. From the formulation of the problem above, the following research questions can be generated: How are the understanding and feelings of children aged $6-8$ years towards the COVID-19 pandemic generated through the meaning of visual representations from the results of visual journal activities?

\section{THEORITICAL FRAMEWORK}

\subsection{Theoritical metafunction}

To function as a complete communication system, the visual, like all semiotic modes, must serve some representation and communication requirements. Kress and Van Leeuwen have adopted the theoretical notion of 'metafunction' from Michael Halliday's work consisting of; ideational metafunction, interpersonal metafunction, and textual metafunction [9].

\subsubsection{Ideational metafunction}

Narrative representation explains that visual forms can be equated with semiotic modes that exist in linguistic form, the difference is that in language it is marked by a verb, while in visual it is marked by elements called vectors [9]. In narrative representation, semiotic mode can be found through elements that can be called vectors. In all narrative structure, there is an object or element that is referred to as participants. When participants are linked by a vector, they are represented as doing something or for each other; this is a vector pattern like narrative or can be called 'presentational' and can be compared conceptually [9]. Narrative patterns serve to present ongoing actions and events, change processes and temporary spatial arrangements. There are different types of narrative processes that can be distinguished based on the types of vectors and the number and types of participants involved according to Kress and Van Leeuwen which are; action process, reactional process, speech and mental processes, conversion process, geometrical symbolism, and circumstances [9].

\subsubsection{Interpersonal metafunction}

The articulation and understanding of social meanings in images derives from the visual articulation of social meaning in face-to-face interaction, the spatial positions allocated to different kinds of social actors in interaction (whether they are seated or standing, side by side or facing each other frontally, etc.) [9]. The interactions that occur in the visual can be seen through the following elements:

\section{The image act and gaze}

According to Halliday, images are divided into two types, some are demanding interaction and some are offering interaction. Demanding interaction means that participants are described as having the characteristics of looking at the audience and demanding the audience to enter into an imaginary relation with him or her [9]. The expressions shown can produce further meanings including; smile which means asking viewers to enter relation of social affinity; cold stare that means asking viewer to relate to participant as an inferior; and defensive gesture means asking viewers to stay away [10]. Images that offer interaction can mean that the participants represented are in the form of information items, objects, or information that is actually presented to the viewer [9]. Usually characterized by participants who are depicted not looking at the viewer, but at other participants in the picture. 


\section{Size of frame and social distance}

Jung divides the distance in the image into six types of social distances; intimate distance, close personal distance, far personal distance, close social distance, far social distance, and public distance [10]. The division of the distance is divided based on how the participants are depicted, what body parts are visible in the picture. It can be concluded that the closer the distance depicted, the expected interaction between the represented participant and the viewer will also be more intimate.

\section{Perspective and the subjective image}

Horizontal angle can reveal whether the image maker and viewer are engaged with the participants being represented or not; frontal angle means to show involvement [9]. Vertical angles can show who has a higher position in the relationship between viewer and participant. If the participant is represented from a high angle by the viewer, then the viewer is depicted as having more power in the relationship. However, if the represented participant is viewed from a low angle, then the participant has power in the relationship. If the participant is drawn at eye level, the participant and the viewer have no difference in strength.

\subsubsection{Textual metafunction}

\section{$\underline{\text { Composition }}$}

Composition combines representational and interactive elements to relate to each other, by being integrated into a meaningful whole [11]. According to Kress and Van Leeuwen, these meanings are connected through three interrelated systems. Information value is the placement of elements gives them specific informational value attached to the various 'zones' of the image: left and right, top and bottom, center and margins. Given and New; Given can be interpreted as the starting point of the message that has been agreed upon, while New can be interpreted as something that is not yet known, or has not been agreed upon by the viewer, so that it must be brought to the attention of the viewer [9]. This can be known through the placement of the objects, on the left side it is usually Given while on the right it is New. Images that point to the right can be interpreted as a progress or progress and vice versa [11]. Ideal and real can be distinguished by placing objects above and below. The top part tends to be an emotional attraction and shows 'what might happen' which is referred to as the Ideal, while the Real is a form of practical information or 'what is' [9]. Centre and margin are utilization of visual composition; usually the element depicted in the middle is the center of information or the core of the information, while Margin is information that is less important than the core [9].

\section{Salience}

Visual elements can be made to be more attractive to the viewer through elements such as foreground or background placement, relative size, contrast in color, differences in sharpness, and so on. The bigger and more prominent the visual figure, the more it becomes the focus of the viewer [11].

\section{Framing}

The presence or absence of a dividing line can disconnect or connect image elements, indicating that they belong or do not belong together in some way [9].

\subsection{Understanding children's drawing}

To understand the meaning in children's drawing, the important thing is the first impression you get or focus on the symbols that appear [12]. Looking at the picture as a whole is necessary to know the first impression that emerges from the picture. Sometimes there are hidden meanings that emerge from the theme of a child's drawing, this is because drawing activities involve subconscious thoughts, feelings, and actions that are raised through the symbols in the image [12]. Children have a natural ability to express narratives through pictures and writing, but many adults do not know the power of drawing as a medium for children by externalizing their experiences, thoughts, and feelings through visual images [9].

\section{METHOD}

The focus of this research is on the meaning making process created by children aged 6-8 years through visual journal using the theory of visual representations by Gunther Kress and Theo Van Leeuwen [9].

Table 1. Research stages

\begin{tabular}{|r|l|l|l|}
\hline No. & \multicolumn{1}{|c|}{ Stages } & \multicolumn{1}{|c|}{ Purpose } & \multicolumn{2}{|c|}{ Result } \\
\hline 1 & Collecting & Gain initial & Used as a \\
literature & knowledge & basis for \\
studies on & and theory \\
related & questions related \\
topics & that will be & \\
\hline
\end{tabular}




\begin{tabular}{|c|c|c|c|}
\hline & & & $\begin{array}{l}\text { asked to the } \\
\text { psychologist }\end{array}$ \\
\hline 2 & $\begin{array}{l}\text { Interview } \\
\text { with child } \\
\text { education } \\
\text { psychologis } \\
\mathrm{t}\end{array}$ & $\begin{array}{l}\text { Get initial } \\
\text { data about } \\
\text { children's } \\
\text { problems } \\
\text { and daily } \\
\text { life during } \\
\text { the } \\
\text { pandemic }\end{array}$ & $\begin{array}{l}\text { Analyzed and } \\
\text { concluded for } \\
\text { research } \\
\text { assumptions } \\
\text { and to } \\
\text { determine } \\
\text { the next } \\
\text { steps }\end{array}$ \\
\hline 3 & $\begin{array}{l}\text { Consulting } \\
\text { the } \\
\text { questions } \\
\text { that will be } \\
\text { asked in } \\
\text { observation } \\
\mathrm{s} \text { to } \\
\text { psychologis } \\
\mathrm{t}\end{array}$ & $\begin{array}{l}\text { Have the } \\
\text { proper } \\
\text { questions } \\
\text { for } \\
\text { observation }\end{array}$ & $\begin{array}{l}\text { A list of } \\
\text { questions } \\
\text { was given to } \\
\text { the mother } \\
\text { for } \\
\text { observation } \\
\text { activities }\end{array}$ \\
\hline 4 & $\begin{array}{l}\text { Conducting } \\
\text { pre- } \\
\text { test/pre- } \\
\text { observation } \\
\text { to two } \\
\text { children }\end{array}$ & $\begin{array}{l}\text { Testing } \\
\text { whether the } \\
\text { steps and } \\
\text { questions } \\
\text { during the } \\
\text { observation } \\
\text { have been } \\
\text { carried out } \\
\text { correctly }\end{array}$ & $\begin{array}{l}\text { The results of } \\
\text { the pre-test } \\
\text { will be } \\
\text { revised and } \\
\text { applied } \\
\text { during the } \\
\text { core } \\
\text { observations }\end{array}$ \\
\hline 5 & $\begin{array}{l}\text { Observing } \\
\text { visual } \\
\text { journal } \\
\text { activities of } \\
\text { participants } \\
\text { for a week }\end{array}$ & $\begin{array}{l}\text { Acquire } \\
\text { children's } \\
\text { visual } \\
\text { journal data }\end{array}$ & $\begin{array}{l}\text { The result of } \\
\text { the visual } \\
\text { journal will be } \\
\text { analyzed by } \\
\text { visual } \\
\text { representatio } \\
\mathrm{n} \text { theory }\end{array}$ \\
\hline 6 & $\begin{array}{l}\text { In-depth- } \\
\text { interview } \\
\text { with the } \\
\text { mother of } \\
\text { the child }\end{array}$ & $\begin{array}{l}\text { To ask the } \\
\text { background } \\
\text { of their } \\
\text { children, } \\
\text { and asking } \\
\text { how the }\end{array}$ & $\begin{array}{l}\text { The results of } \\
\text { the visual } \\
\text { journal and } \\
\text { interview will } \\
\text { be analyzed } \\
\text { and }\end{array}$ \\
\hline
\end{tabular}

\begin{tabular}{|l|l|l|l|}
\hline & & $\begin{array}{l}\text { visual } \\
\text { journal } \\
\text { activities } \\
\text { was carried } \\
\text { out }\end{array}$ & $\begin{array}{l}\text { concluded } \\
\text { together }\end{array}$ \\
\hline 7 & $\begin{array}{l}\text { Analyze } \\
\text { and } \\
\text { interpret } \\
\text { data }\end{array}$ & $\begin{array}{l}\text { Acquire } \\
\text { research } \\
\text { conclusions } \\
\text { from } \\
\text { observation } \\
\text { s and } \\
\text { interviews }\end{array}$ & $\begin{array}{l}\text { Research } \\
\text { conclusion }\end{array}$ \\
\hline
\end{tabular}

\subsection{Participants}

The participants are three children aged six to eight who live in Bandung, Indonesia. The age range is based on two theories described by Dyson and Lowenfeld. The participants are children who are in the pre-schematic age, who begin to use writing and drawing as a mediator, are already familiar with language of words and still draw spontaneously [2][3].

Table 2. Characteristics of the five children

\begin{tabular}{|l|l|l|l|}
\hline & Al & AR & NA \\
\hline Age & $\begin{array}{l}6 \text { years } \\
9 \\
\text { months }\end{array}$ & 7 Years & $\begin{array}{l}8 \text { Years 5 } \\
\text { months }\end{array}$ \\
\hline Gender & Girl & Boy & Girl \\
\hline Siblings & $\begin{array}{l}\text { Older } \\
\text { sister, } \\
\text { younge } \\
\text { r sister }\end{array}$ & $\begin{array}{l}\text { A younger } \\
\text { sister }\end{array}$ & $\begin{array}{l}\text { Two } \\
\text { younger } \\
\text { sisters }\end{array}$ \\
\hline $\begin{array}{l}\text { Occupatio } \\
n\end{array}$ & $\begin{array}{l}\text { Civil } \\
\text { servant } \\
\text { mother }\end{array}$ & Entreprene & Entreprene \\
\end{tabular}

\subsection{Research stages}

This research was conducted by observing children's visual journal activity at their home within a week. Researcher did not participate directly during the observations, this is based on the advice of a child education psychologist and graphologist, Laksmira Ratna Bayuardi, Dip. Child Psy., MHA, CAT, who stated that children need a safe and comfortable condition while doing the activities, so it is best that 
the instructions are carried out by the child's parents. Therefore, the instructions were given by the mother of each child. All the visual journal materials were sent to each child's home. The researcher prepared an A5 drawing book, and a pack of colorful markers. Before the activity was carried out, the mother was asked to give some questions to the child. The questions asked to the child were about their experiences, feelings, and opinions about the situation of COVID-19 pandemic.

\section{RESULT}

\subsection{Analysis stages}

All results of the visual journal will be analyzed through four stages, including:

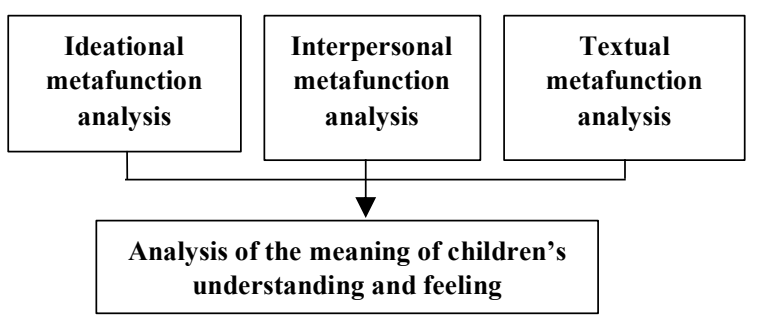

Figure 1 Analysis Stages

\subsection{AI's visual journal}

\subsubsection{Ideational metafunction of AI's visual journal}

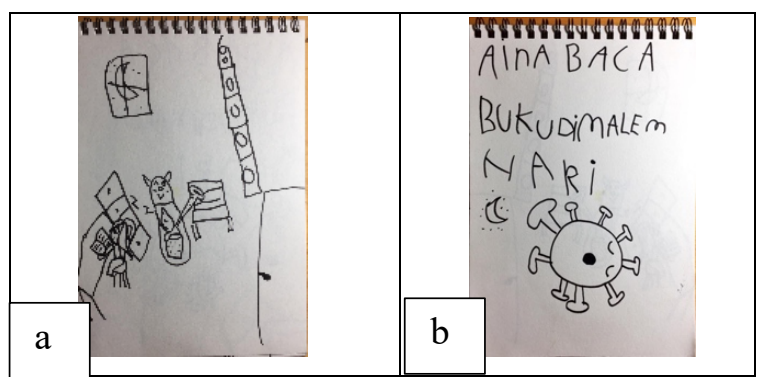

Figure 2 AI's visual journal; (a) First picture, (b) second picture.

In the first picture of AI's visual journal, she depicts herself reading a book. AI depicted as a main Actor in the picture. The Goal is the book depicted being held by the Actor. It can be concluded that the resulting process is a transactional process. Participant AI is described smiling while facing the book. This means that she enjoys reading the book. AI describes the setting by drawing a table, cupboard, and a toy organizer to described a study room. There is a vector that function as an Accompaniment which is a depiction of a sleeping cat. There is also a depiction of the corona virus which described as The Reacter who reacts to the situation that were described.

\subsubsection{Interpersonal metafunction of AI's visual journal}

Through the analysis of action and gaze of the participant, it can be seen that AI's visual journal is offering interaction. The main Actor is facing the book, and not showing her frontal view. Through the size of the frame and social distance, it can be seen that AI depicts a far social distance by showing all parts of the participant's body and surrounding environment. From the perspective, through a vertical angle it can be seen that the participant is depicted from a lower angle than the viewer. The participant's gestures can be interpreted that she has a purpose to provide information to the viewer about her activities without the purpose of making interaction with the viewer. It can be concluded that AI produces an interactions or relationships that are formal, distant, and there is no closeness between the participants and the viewer.

\subsubsection{Textual metafunction of AI's visual journal}

Through observations from left to right, it can be seen that participants AI are depicted on the left which indicates a Given elements, and the door on the right is New elements. Given means an agreed starting point from the message [4]. It can be concluded that the description of "AI is reading a book" is information that has been agreed upon by participants and viewers. In the picture, the depiction of the door is on the right, so that the door is interpreted as something new, or must be noticed by the viewer. The proportion of the door image is depicted in large size and closer to the viewer, so the door is used as an emphasis. While the depiction of the main Actor, is described with a relatively small size and is further away from the viewer. The bigger the figure, the more it attracts the attention of viewers [12]. It can be interpreted that AI wants the participant not to be the focus of viewer attention, but the door is the main focus in the picture. This can mean that AI needs personal space for herself to enjoy her activities, or that the distance described is included in social distancing activities to viewers. AI does not explicitly describe the feelings she feels during the pandemic. 
But, AI depicts participants in relatively small size, and this is done in each of her drawing in visual journal. The depiction of small people can be interpreted as incompetence, fear, and depression [12]. However, the results of this interpretation are still in the form of assumptions and must be tested or validated by the competent authorities which is psychologist.

\subsection{AR's Journal Visual}

\subsubsection{Ideational metafunction of AR's visual journal}

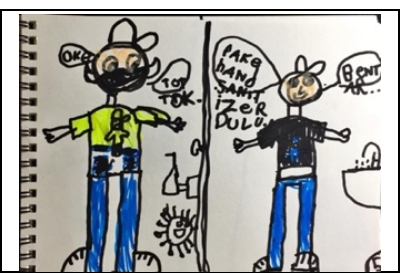

Figure 3 AR's visual journal.

Participants can be identified through the conversation that is depicted, and how AR describes both participants with the same height and body proportions. So that the two participants can be identified as AR and AR's friends. In the narration, it is told that AR's friend who wears a yellow shirt and a blue pants is visiting AR's house. AR's friend knocked on AR's door. Then, participants AR answered by telling his friends to use hand sanitizer first. Through this process, it can be concluded that AR's friend is the Actor, and AR is the Goal. This process provides a bidirectional transaction. AR participants have smiling expressions, while AR's friend expression is not visible because he is depicted wearing mask. However, AR friend's eyes look on the doorknob, signaling that AR's friend would open the door. There is another participant described as The Reacter, which is the depiction of the corona virus. It is depicted with a happy expression with a mouth wide open. It can be interpreted that the corona virus responds to the condition outside the AR's house. AR explained that he wanted to interpret the situation outside the house that was dangerous because there is so much corona virus. He describing it through the expression of the corona virus. AR said that "The corona virus is happy because there are many other corona viruses outside the house". The setting depicted can be seen through the depiction of the hand sanitizer station, door, and sink. The door is depicted with a vertical line in the middle of the image to separate the setting outside the house and inside the house. AR's friend was described as being outside the house, while AR participant was described as being inside the house. In this picture, hand sanitizer is included in the Means because it is a tool used in the structure of the interaction that occurs.

\subsubsection{Interpersonal metafunction of AR's visual journal}

Through the analysis of visible elements, the image has a demanding type of interaction, the expression depicted through participant AR is smiling and showing his frontal view, the distance depicted is quite close because the viewer can see all parts of the body of the represented participant at a close distance. Through a vertical angle it can be seen that the represented participant has the same position as the viewer. This means that the represented participant invites viewer to be involved in the interaction described. Although in the picture it is told that AR's friend come and knock on the door, AR depicts himself facing the viewer, not facing the door or AR's friend. This can be interpreted that AR does not only tell his friends to use hand sanitizer before entering his house, he also invites viewers to do the same thing when visiting somebody's house. Through a vertical angle, it can be seen that participants and viewers have the same position or there is no difference in power.

\subsubsection{Textual metafunction of AR's visual journal}

Through observations from left to right, it can be seen that AR's friend who wears a yellow shirt and comes to AR's house is a form of Given in the picture. Meanwhile, AR ordering his friend to use hand sanitizer is a New form. Both participants are objects that are colored by AR, while the other objects are not. This means that both participants are the focal point or emphasis of the structure described which is expected to attract the attention of the viewer. There is framing through the depiction of the door. This means that the two participants are separated by a door and are in two different area. This description can mean that AR wants to emphasize that AR's friend who come to his house are not allowed to enter if he has not used hand sanitizer and this is used as an important information and the focus of viewers. The second form of AR visual journal is an invitation to viewers to do the things depicted in the picture, which is to always use hand sanitizer before visiting someone's house. Through AR's drawing, there is a repetition of the depiction of participants. The participants are depicted with their arms stretched out to the sides. This means that he has a desire to relate to the environment or other people, or a desire to interact [12]. This is a continuation of the interpersonal analysis that $\mathrm{AR}$ invite viewers to interact with the participants. It can 
be concluded that in this pandemic situation, AR has a desire to interact with other people and provide information about the activities he is doing, and hopes that others will be interested in doing the same.

\subsection{NA's visual journal}

\subsubsection{Ideational metafunction of $N A$ 's visual journal}

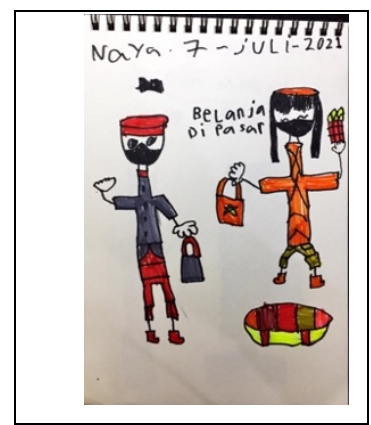

Figure 4 NA's visual journal.

There are two participants in NA's picture. The first participant is described as a girl wearing an orange shirt, an orange hat, and a mask which is a depiction of NA. The second participant is a man wearing a gray shirt, red hat, and red pants which NA mentioned as a hotel clerk. NA is depicted holding a shopping bag and a potato snack. These can be identified as Means in the narrative structure. Through the narrative structure and explanation through the text, it can be concluded that NA describes shopping activities in the market. NA is the main Actor who shop at the market, so the structure of the picture shows the transactional process. The hotel clerk described is an Accompaniment, because he does not enter into the main action. Participants are depicted wearing masks so that the expressions depicted are not visible. The setting of the place is depicted through the depiction of a bowl which described a market.

\subsubsection{Interpersonal metafunction of $N A$ 's visual journal}

Through the picture, it can be seen that the participant demands the viewer to enter into the interaction that occurs in the picture. The participant's expression was not clearly visible, but through the depiction of the eyes it could be seen that the participant had a smiling expression. This means that viewers are drawn into a close relationship. Through the social distance, it can be seen that NA gives the meaning of impersonal distance. Participants show the frontal view, this means that viewers are invited to engage in interaction. Through a vertical angle, it can be seen that the audience and participants have the same equal position. This means that viewers are invited to enter into interactions with equality.

\subsubsection{Textual metafunction of NA's visual journal}

Through the picture, it can be seen that the hotel clerk participants are a form of Given or an information that has been agreed upon by the viewer. Meanwhile, the picture of the NA participants is a form of New information that is expected to be the focus of the viewer's attention. Through the analysis of gestures, it can be seen that hotel clerk participants are depicted with waving hands, and NA participants are depicted with eyes that look like smiling. So, although the core of the interaction is shopping at the market, with this description, viewers can see that hotel clerk participants greet NA participant. This means that NA wants to describe the friendliness of the people around her through the depiction of the hotel clerk's eyes that look like they are smiling. Although it was not explained that the two participants greeted each other, through hand gestures that looked like waving, it could be concluded that they were greeting each other. There is a repetition in depiction of participants in the NA visual journal. She tends to draw the participant's neck with a size that is longer than the proportion of the body. Neck that is depicted as very long means that the child has difficulty achieving a desire [12]. However, the results of this interpretation are still in the form of assumptions and must be tested or validated by the competent authorities which is psychologists.

\section{CONCLUSIONS}

It can be concluded from all the results of the visual journal, that the children dominantly depicted himself as the main Actor. The depiction of the Actor is dominantly depicted in a long shot. This means that the social distance depicted in the picture is impersonal or not intimate. Their self-representation can also be interpreted that the resulting visual journal is really used as a reflection medium of their daily activities. From the results of this study, it can be concluded that visual journal activities carried out by children help adults to find out their children's and emotions regarding to COVID-19 pandemic situation. The result of the meaning in children's visual journal is that children understand the situation of the pandemic, the existence of the corona virus, and how they deal with the current pandemic situation. There are children who actually provide information about the activities they are doing during the pandemic 
through the offering type of interaction. However, more visual journals resulted in the demanding type of interaction. Viewers are invited to enter into the interactions that occur, and some even try to invite viewers to do the activities that are told in the narrative. The children's feelings are described in the visual journal, this can be known through the repetition of the drawing of the participant's gestures. Some children feel happy and want to interact with viewers, some have negative emotions. Children's visual journals and their visual representations provide clues for adults about their experiences and feelings about a situation. Children can use visual journal as a familiar and non-intimidating medium to share their experiences. In addition, children's visual journal produces hidden meanings resulting from the analysis of the symbols created in them. Sometimes the child does not realize that they had made meaning about their feelings in the symbols they create. This makes visual journal an effective communication medium, and is proven to be more able to express children's feelings in a valid and honest manner.

This research still has some shortcomings. First, this research was conducted remotely, so the researcher did not see the visual journal activities directly and did not get to know or approach the participants first. Thus, the interaction results that appear in the visual journal are entirely impersonal interactions. Further research can emphasize the aspect of the researcher's presence in observation activities so that more in-depth and intimate analysis results can be produced. Second, the interviews conducted with the mothers after the observation were not conducted to all the mothers of the participants, so the researcher recommends further research to deepen the interview stage after the observations were carried out. Third, this study only analyzed the main layers of the meaning of children's visual journal regarding their feelings and understanding. Further research can take advantage of the stages of analysis carried out in this study to be used in subsequent analyzes with more in-depth methods in order to create analytical findings regarding the following layers. Researchers recommend practitioners to be able to use the results of the visual journal analysis as a basis for following up on children protection by finding out more detailed stories about experiences, feeling, and reactions from children that experienced a difficult circumstance. Practitioners can detect a child's psychological state or children's experiences when they are faced with difficult situations such as natural disasters, learning activities in school, child abuse, bullying, and so on through children's visual journals. Knowing children's needs through visual journals can be used as a way to detect current and future needs of children.

\section{REFERENCES}

[1] D.V. Putsanra, Data mengenai Arti PSBB yang Dibuat untuk Cegah Penyebaran Corona di Indonesia [cited 2020 Nov 05] Available from: https://tirto.id/eMXT.

[2] N. Azizah, Data mengenai Ahli Sebut Pandemi Berdampak pada Psikologis Anak [cited 2021 August 03]. Available from: https://www.republika.co.id/berita/qhdl39463/a hli-sebut-pandemi-berdampak-pada-psikologisanak.

[3] I.R. Waridha, Kajian Jurnal Bergambar Sebagai Media Komunikasi Anak kepada Orang Dewasa di Sekitarnya, Jurnal Sosioteknologi, Vol. 16, No. 3, Bandung, Indonesia, 2017.

[4] C. Katz, Z. Barnetz, I. Hershkowitz, The Effect of Drawing on Children's Experiences of Investigations Following Alleged Child Abuse, Child Abuse \& Neglect The International Journal, 2014.

[5] K. Ring, Young children drawing: the significance of the context. College of Ripon and York, 2001.

[6] M. Papandreou, Communicating and Thinking Through Drawing Activity in Early Childhood, Journal of Research in Childhood Education,2012.

[7] J.O. Anim, The role of drawing in promoting the children's communication in Early Childhood Education, Oslo and Akerhesus University College of Applied Science. Dublin Institute of Technology and University of Malta, 2012.

[8] K. Ring, What mothers do: everyday routines and rituals and their impact upon young children's use of drawing for meaning making, International Journal of Early Years Education, York St John College, United Kingdom, 2006.

[9] G. Kress, T. Leeuwen, V. Reading Images - The Grammar of Visual Design, New York, 2006.

[10] C.K. Jung, \& T.H. Ly, Multimodal Discourse: A Visual Design Analysis of Two Advertising Images, International Journal of Contents, Vol.11, No.2, South Korea, 2015. 
[11] R.M. Sihombing, Pergeseran Representasi Sosok Ibu Pada Ilustrasi Buku Anak Indonesia Tahun (1973-2013), Institut Teknologi Bandung, 2014.

[12] M. Farokhi, M. Hashemi, The Analysis of Children's Drawing: Social, Emotional, Physical, and Psychological aspects, Procedia Social and Behavioral Sciences, vol. 30, 2011, pp. 2219-2224. 